\author{
Nebava M. I. [1; ORCID ID: 0000-0001-6933-8702], \\ Candidate of Economics (Ph.D.), Professor, \\ Li Yanan [1; ORCID ID: 0000-0002-6652-4953], \\ Post-graduate Student
}

\author{
'Vinnytsia National Technical University, Vinnytsia
}

\title{
DIRECTIONS AND STRATEGIC OBJECTIVES OF THE DEVELOPMENT OF UKRAINE'S BANKING SECTOR IN THE PERIOD OF ECONOMIC INSTABILITY
}

The article examines the directions and strategic goals of the banking sector of the national economy in the period of economic instability. The areas of anti-crisis measures have been identified on the basis of foreign experience of central banks in the crisis. The conditions and risks of the banking sector of Ukraine in the conditions of crisis have been characterized. The strategic directions and goals of the banking sector development have been determined. The list of international organizations that provide information support to promote the financial stability of the NBU has been given. Macroeconomic factors that will determine the development of the banking sector in the future have been highlighted, namely: customer focus, regulatory base review, technology management, cyber risk reduction, financial-technical projects and large IT companies, rethinking human resources.

Keywords: national economy; banking system; macro prudential regulation; macroeconomic factors; development mechanism; participants of the banking sector; risks; crisis.

Topicality. The spread of the COVID-19 epidemic caused economic instability, which disrupted the stability of the country's banking system. However, during the crisis, the banking sector showed little risk of destabilization due to the fact that it had a significant margin of financial stability and lending potential. Such positive changes have become possible due to high-quality and timely macro prudential policy, which is able to identify and assess risks to ensure the financial stability of the country's banking system.

Analysis of recent sources and publications. Many Ukrainian scientists have studied the problems of the development of the banking sector of the national economy in the period of economic instability, in particular: 0. Baranovsky, 0. Vovchak, M. Glushchenko, I. Drozd, 114 
L. Dudynets, A. Epifanov, O. Lapko, V. Mishchenko, A. Moroz, N. Savina, T. Smovzhenko, M. Savluk, O. Kozmenko, V. Korneyeva, K. Rozhkova, N. Sheludko and others. However, nowadays the developments of the banking sector are insufficiently covered by the work of scientists, given the consequences of the corona crisis due to the spread of the COVID-19 epidemic, as well as the constant changes in the economy.

Taking into account the significant achievements of domestic science on this issue, we note that the problem of development of the banking sector of Ukraine in the period of economic instability at the present stage is extremely acute and requires further research. The information base of the study is strategic documents, legislation, official publications of the NBU, which are based on the experience of the EU and the recommendations of the Basel Committee on Banking Supervision.

The purpose of the article is to study the conditions and risks of the banking sector of Ukraine, as well as to determine the directions and strategic goals of its development.

Presentation of the main research material. The macro prudential policy strategy states that the strategic goal of macro prudential policy is «to ensure the state of the financial system, in which it is able to properly perform the basic functions - financial intermediation and payments - and successfully withstand crises, and its achievement will contribute to sustainable economic growth» [7, p. 4].

We would like to add that in addition to the strategic goal, the NBU also defines intermediate ones. These goals are: limiting and preventing excessive credit growth and debt burden, limiting and preventing liquidity shortages and significant gaps between assets and liabilities, increasing the stability of financial infrastructure, limiting direct and indirect concentration of risks, limiting the systemic impact of distorted incentives to reduce moral hazard.

Banking market experts distinguish between the crisis-crisis and the economic crisis: «The Covid-crisis is not an economic crisis, but it has a very serious impact on the economy, primarily due to reduced consumption. This is the first time in our history when the economic crisis is not accompanied by a banking crisis» [1]. Based on the foreign experience of central banks in the crisis, the National Bank of Ukraine (NBU) [2] has developed three areas of anti-crisis measures, which relate to: monetary policy (reduction of interest rates to 6\%); additional liquidity support instruments (interest rate swap); prudential supervision (suspension of bank inspections, cancellation of stress 
testing, easing of requirements for calculating credit risk for the period of credit holidays).

Table. 1 provides a detailed description of typical threats to the banking sector in a crisis.

Table 1

Characteristics of conditions and risks of the banking sector of Ukraine in the crisis

\begin{tabular}{|l|l|}
\hline \multicolumn{3}{|c|}{ Type of threat } \\
\hline \multicolumn{2}{|c|}{ NATIONAL ENVIRONMENT } \\
\hline $\begin{array}{l}\text { Internal conditions } \\
\text { Mistakes in strategic planning or } \\
\text { forecasting }\end{array}$ & High inflation rate \\
\hline $\begin{array}{l}\text { Improper compliance with the bank's } \\
\text { regulations, which in turn leads to a } \\
\text { decrease in the bank's liquid assets }\end{array}$ & $\begin{array}{l}\text { Financial, geopolitical, political and other } \\
\text { crises and instability of the regulatory- } \\
\text { legal base }\end{array}$ \\
\hline Weak staff potential of employees & Change in central bank regulations \\
\hline $\begin{array}{l}\text { Mass non-repayment of credit resources } \\
\text { as a result of non-compliance with profits }\end{array}$ & $\begin{array}{l}\text { Gradual increase in financial crimes } \\
\text { related to the banking sector }\end{array}$ \\
\hline $\begin{array}{l}\text { Insufficient marketing research of the } \\
\text { entire banking services market }\end{array}$ & $\begin{array}{l}\text { Fierce competition affecting the entire } \\
\text { banking services market }\end{array}$ \\
\hline \multicolumn{2}{|c|}{ INTERATIONAL ENVIRONMENT conditions } \\
\hline \multicolumn{2}{|c|}{ The state of the economy of trading partners and the level of world trade } \\
\hline Impact of geopolitical risks and international uncertainty \\
\hline Crisis financing by governments and central banks \\
\hline Infusion of capital to developing countries \\
\hline Prices for raw materials and financial assets \\
\hline
\end{tabular}

Source: compiled by the authors based on [3-4]

After analyzing the table, it is clear that the main threats affecting the banking sector can be divided into internal and external. However, the new challenges that financial crises can cause today are largely unpredictable. Particular attention should be paid to the latest crises that threaten the work and security of the banking sector. Regarding the international environment, the following trends are observed: trading partner economies and world trade are recovering from the COVID crisis of the first half of the year, but the risks of a new recession due to the second wave of the pandemic are high. To a large extent, this is facilitated by the governments and central banks of many countries and MFIs, which continue to stimulate recovery by fiscal and monetary means.

Geopolitical and geoeconomic risks have declined since the advent of COVID vaccines, which has also helped economic recovery. Interest in the assets of emerging markets (EMs) varies by region. Commodity 
prices and financial assets are rising to pre-crisis levels. The prospects for international containment of Russia as an aggressor country have improved due to the expected position of the United States [3-4].

The main challenges to stability are the need to strengthen quarantine to reduce the incidence of COVID-19, as well as the slow progress of Ukraine's cooperation with the IMF. At the same time, the economy is recovering fairly quickly from the effects of the coronary crisis. This is facilitated by: the situation in key export markets, wage growth, soft monetary and fiscal policies. Due to the reduction of the key rate to the lowest level in history $-6 \%$, the cost of loans to borrowers has reached an all-time low. Execution of the 2021 state budget is complicated by optimistic estimates of key revenues, and the planned financing of its deficit from domestic resources is a difficult task [3-5].

In order to ensure financial stability in times of economic instability, the coordinated work of all financial market participants is required.

Based on the above, we can say that with the necessary effective mechanism for the development of the banking sector of the economy, which has the ability to respond in a timely manner to changes in geospace and within the country, it becomes possible to identify strategic directions of the banking sector. Such areas are: financial stability, macroeconomic development, financial inclusion, development of financial markets, innovative development. In turn, each of these areas has its own strategic goals. Let us consider them in more detail in Fig.

The consideration of such an area as the resilience of the financial sector to challenges (shocks, uncertainties) deserves special attention in today's world. In economics, there is a generalizing concept called economic turbulence. Note that economic turbulence is «the extreme degree of instability of the socio-economic system, when the probability of reaching the point of its bifurcation is extremely high. In the process of systemic turbulence (which includes the Ukrainian economic system from 1991 to the present), the logic and sequence of socio-economic processes are violated» [6].

As noted, the main task of the National Bank during the crisis is to develop recommendations and publish plans and intentions for participants in the banking system in the near future. To promote financial stability, the NBU focuses on the recommendations of the BCBS (Basel Committee on Banking Supervision at the Bank for International Settlements), ESRB (Entertainment Software Rating Board - a non-governmental self-regulatory organization that evaluates and 
subsequently assigns software ratings), norms CRR / CRD IV (EU law aimed at reducing the likelihood of bank failures).

\begin{tabular}{|c|c|}
\hline Financial stability & $\begin{array}{l}\text { Effective regulation of the financial sector and } \\
\text { improvement of supervisory approaches } \\
\text { Transparent financial sector } \\
\text { Resilience of the financial sector to challenges (shocks) } \\
\text { Improving the quality of corporate governance and risk } \\
\text { management in the financial sector }\end{array}$ \\
\hline $\begin{array}{l}\text { Macroeconomic } \\
\text { development }\end{array}$ & $\begin{array}{l}\text { Ensuring the sustainability of public finances } \\
\text { Promoting lending to the economy } \\
\text { Strengthening the protection of creditors and investors } \\
\text { Creating conditions for attracting long-term resources }\end{array}$ \\
\hline Fin & $\begin{array}{l}\text { Improving the availability and level of use of financial } \\
\text { services } \\
\text { Strengthening the protection of the rights of consumers of } \\
\text { financial services } \\
\text { Increasing the level of financial literacy of the population }\end{array}$ \\
\hline $\begin{array}{l}\text { Development of } \\
\text { financial markets }\end{array}$ & $\begin{array}{l}\text { Promoting the development of non-bank financial services } \\
\text { markets } \\
\text { Effective capital market infrastructure } \\
\text { Creation of liquid markets for financial instruments and } \\
\text { mechanisms to reduce the risks of financial transactions } \\
\text { Integration of the country's financial market into the global } \\
\text { financial space }\end{array}$ \\
\hline $\begin{array}{l}\text { Innovative } \\
\text { development }\end{array}$ & $\begin{array}{l}\text { Development of open financial market architecture and } \\
\text { oversight } \\
\text { Ensuring the development of the FinTech market, digital } \\
\text { technologies and regulatory platforms } \\
\text { Ensuring the development of SupTech \& RegTech } \\
\text { Development of the digital economy }\end{array}$ \\
\hline
\end{tabular}

Fig. Directions and strategic goals of the banking sector development (grouped by the author according to [6])

The subjects of the banking system, based on the principles necessary for the formation of an effective structure of the banking sector and with the help of methods of legal and financial and economic influence and tools of macro prudential regulation, contribute to the sustainable growth of the national economy.

That is, the stability and development of the banking sector of Ukraine is greatly influenced by its participants, as they provide the main mission - to improve the welfare of citizens by ensuring the effective accumulation, distribution and circulation of financial resources in the national economy.

Thus, financial stability in the country depends not only on banks, but also on non-banking and other financial institutions and their 
interaction with each other. This necessitates effective interaction between the NBU and other regulators of the financial sector to implement macro prudential policy measures. For this purpose, in 2015, the Presidential Decree established the Financial Stability Board [8].

The main task of the Financial Stability Board is to identify and level risks for the country's financial system.

In promoting financial stability, the NBU focuses on international recommendations. The interdepartmental interaction of the participants of the banking sector is shown in the part of the regulators of the sector, accordingly it is necessary to find out their sphere of influence (Table 2).

Thus, we see five main subjects of state regulation of the banking sector, which have different legal status, perform different functions and powers, as well as different spheres of influence. The sphere of influence of these regulators includes a large number of enterprises, organizations and institutions, other governing bodies. In the article, the participants of the banking sector understand the above regulators and enterprises that belong to their sphere of influence.

According to the research, the key players in the banking sector are:

- National Bank of Ukraine;

- Ministry of Finance of Ukraine;

- National Commission on Securities and Stock Market (NCSSM);

- National Commission for State Regulation of Financial Services Markets (Natskomfinposlug) (currently in liquidation);

- Deposit Guarantee Fund for Individuals (DGFI).

Characteristics of banking sector regulators and their sphere of influence*

\begin{tabular}{|l|l|l|}
\hline № & \multicolumn{1}{|c|}{$\begin{array}{c}\text { Authority definition / legal } \\
\text { status }\end{array}$} & \multicolumn{1}{|c|}{ Sphere of influence } \\
\hline \multicolumn{3}{|c|}{ NATIONAL BANK OF UKRAINE (NBU) } \\
\hline 1. & $\begin{array}{l}\text { special central body of public } \\
\text { administration, legal status, } \\
\text { tasks, functions, powers and } \\
\text { principles of organization of } \\
\text { which are determined by the } \\
\text { Constitution of Ukraine, the } \\
\text { Law of Ukraine "On the }\end{array}$ & $\begin{array}{l}\text { banks that have a banking license and } \\
\text { submit reports to the National Bank of } \\
\text { Uational Bank of Ukraine" and } \\
\text { other laws }\end{array}$ \\
\hline
\end{tabular}


Continuation of Table 2

\begin{tabular}{|c|c|c|}
\hline \multicolumn{3}{|c|}{ MINISTRY OF FINANCE (MINFIN) } \\
\hline 2. & $\begin{array}{l}\text { The Ministry of Finance of } \\
\text { Ukraine is the central } \\
\text { executive body that } \\
\text { formulates and implements } \\
\text { the state financial and } \\
\text { budgetary policy, as well as } \\
\text { determines the policy in the } \\
\text { customs and tax spheres. }\end{array}$ & $\begin{array}{l}\text { central executive bodies (State } \\
\text { Treasury Service, State Tax Service, } \\
\text { State Customs Service, State Financial } \\
\text { Monitoring Service); institutes, } \\
\text { institutions, state and state enterprises, } \\
\text { educational institutions of the ministry }\end{array}$ \\
\hline \multicolumn{3}{|c|}{ NATIONAL COMMISSION ON SECURITIES AND STOCK MARKET (NCSSM) } \\
\hline 3. & $\begin{array}{l}\text { state collegial body that } \\
\text { carries out state regulation of } \\
\text { the capital market and } \\
\text { supervision of its participants, } \\
\text { ensures the stability, } \\
\text { competitiveness and } \\
\text { development of capital } \\
\text { markets, as well as protects } \\
\text { the interests of investors, } \\
\text { prevents abuse and } \\
\text { delinquency }\end{array}$ & $\begin{array}{l}\text { issuers; self-regulatory organizations } \\
\text { of professional market participants; } \\
\text { securities investors; professional } \\
\text { participants; consumers (enterprises, } \\
\text { authorities); suppliers (households, } \\
\text { enterprises, non-profit, institutional } \\
\text { investors - banks, trusts, investment } \\
\text { funds, pension funds and insurance } \\
\text { companies); entities serving the market } \\
\text { (consulting, advertising firms; } \\
\text { participants servicing the issue, } \\
\text { brokerage, dealership, representation, } \\
\text { depository, clearing, etc.); bodies that } \\
\text { regulate the activities of market } \\
\text { participants (state and local } \\
\text { governments, non-state - the stock } \\
\text { exchange, various professional } \\
\text { organizations of market participants). }\end{array}$ \\
\hline \multicolumn{3}{|c|}{$\begin{array}{l}\text { NATIONAL COMMISSION IMPLEMENTING STATE REGULATION IN THE FIELD OF } \\
\text { FINANCIAL SERVICES MARKETS (NATIONAL COMFIN SERVICES) }\end{array}$} \\
\hline 4. & $\begin{array}{l}\text { a state collegial body } \\
\text { subordinated to the President } \\
\text { of Ukraine and accountable to } \\
\text { the Verkhovna Rada of } \\
\text { Ukraine }\end{array}$ & $\begin{array}{l}\text { insurance companies, private pension } \\
\text { funds, credit unions, trust companies, } \\
\text { pawnshops, leasing companies, } \\
\text { factoring companies, } \\
\text { investment institutions }\end{array}$ \\
\hline \multicolumn{3}{|c|}{ DEPOSIT GUARANTEE FUND FOR INDIVIDUALS (DGFI) } \\
\hline 5. & $\begin{array}{l}\text { public law institution, which } \\
\text { on behalf of the state } \\
\text { guarantees the return of } \\
\text { deposits to depositors in the } \\
\text { event of liquidation of the } \\
\text { bank, its purpose - to protect } \\
\text { the rights and legitimate } \\
\text { interests of bank depositors }\end{array}$ & bank depositors \\
\hline
\end{tabular}

Source: grouped by author according to [8-15] 
There is a relationship between these participants and their spheres of influence, and cooperation is documented. In particular, there is a current Memorandum of Interaction and Cooperation between key participants which states that the parties will work fruitfully in the implementation of financial sector reforms through the following methods [8]:

- to ensure the implementation by the responsible parties of certain measures (projects), in accordance with the principles of project management, to create joint working groups for project implementation, to hold working meetings at all levels, to provide mutual assistance in project implementation, to participate in discussions, etc.;

- to establish a steering committee, in which the heads of the parties will take part and the activity of which will be coordinated by the Chairman of the National Bank of Ukraine. Decisions of the Committee are taken with the consent of all parties;

- in order to implement uniform approaches to monitoring and preparation of consolidated status reporting on draft strategies, the parties will provide monthly reports on the status of project implementation at committee meetings;

- to organize and conduct joint public events on topical issues related to the implementation of the strategy and implementation of reforms in the financial sector of Ukraine, publish information about their cooperation on the official websites of the parties.

Thus, the Memorandum confirms that the interaction of the banking sector is a way to: further strengthen financial stability, stimulate macroeconomic development, development of financial markets, further implementation and expansion of financial inclusion, introduction and coverage of the banking sector with innovations.

Conclusion. The results of the study showed that in a changing business environment it is necessary to focus on the following macroeconomic factors that will determine the development of the banking sector: customer focus, regulatory review, technology management, cyber risk reduction, fintech projects and large IT companies, rethinking human resources.

The article also examines that the main threats affecting the banking sector are divided into internal and external. However, there are new crises that threaten the work and security of the banking sector. This served as a proof that it is necessary to create an effective mechanism for the development of the banking sector of the country's economy, which would respond in a timely manner to changes taking place in geospace and within the country. Such areas are: financial 
stability, macroeconomic development, financial inclusion, development of financial markets, innovative development.

Based on the current legislation, five main subjects of state regulation of the banking sector have been identified, which have different legal status, perform different functions and powers, as well as different spheres of influence. Such entities are: the NBU, the Ministry of Finance, the NCSSM, the DGFI, the NCRFS. The sphere of influence of these regulators includes a large number of enterprises, organizations and institutions, other governing bodies.

1. Катерина Рожкова. Як банківський сектор пережив коронакризу? Центр економічної стратегіï. URL: https://ces.org.ua/yak-bankivskyy-sektor-koronakryzu/ (дата звернення: 02.03.2021). 2. Про Національний банк України : Закон України. Відомості Верховної Ради України. № 679-XIV від 20 травня 1999 року. [Чинний від 2021-01-01]. URL: https://zakon.rada.gov.ua/laws/show/679-14/page\#Text (дата звернення: 17.02.2021). 3. Звіт про фінансову стабільність. НБУ, грудень 2020. URL: https://bank.gov.ua/admin_uploads/article/FSR_2020-H2.pdf?v=4 (дата звернення: 09.02.2021). 4. The $\$ 10$ trillion rescue: How governments can deliver impact. URL: https://www.mckinsey.com/ /media/McKinsey/Industries/Public\%20Sector/Our\%201 nsights/The $\% 2010 \% 20$ trillion $\% 20$ dollar\%20rescue $\% 20$ How $\% 20$ governments $\% 20$ can $\% 20$ deliver\%20impact/The-10-trillion-dollar-rescue-How-governments-can-deliverimpact-vF.pdf (дата звернення: 09.02.2021). 5. Стратегія макропруденційної політики. НБУ. URL: https://old.bank.gov.ua/doccatalog/document?id=83019081. (дата звернення: 09.02.2021). 6. НБУ: офіційний сайт. https://bank.gov.ua/admin_uploads/article/Strategy_FS_2025.pdf?v=4 (дата звернення: 09.02.2021). 7. Стратегія макропруденційної політики: HБУ. URL: URL: file://C:/Users/User/Downloads/Strategy_MaP.pdf (дата звернення: 09.03.2021). 8. Про Національний банк України: Закон України від 20.05.1999 № 679-XIV. Відомості Верховної Ради України. 1999. № 29. Ст. 238. Оновлено 01.01.2021р. URL: https://zakon.rada.gov.ua/laws/show/679-14/page\#Text (дата звернення: 17.02.2021). 9. Про Національну комісію, що здійснює державне регулювання сфері ринків фінансових послуг : Указ Президента України від 23.11.2011 № 1070. Втрата чинності 07.07.2020 p. URL: https://zakon.rada.gov.ua/laws/show/1070/2011\#Text (дата звернення: 17.02.2021). 10. Про припинення Національної комісії, що здійснює державне регулювання у сфері ринків фінансових послуг: Указ Президента України від 30.06.2020 р. № 259/2020. URL: https://zakon.rada.gov.ua/laws/show/259/2020\#Text (дата звернення: 17.02.2021). 11. Про Національну комісію 3 цінних паперів та фондового ринку : Указ Президента України від 23.11.2011 р. № 1063/2011. Оновлено 07.07.2020р. URL: https://zakon.rada.gov.ua/laws/show/1063/2011\#Text (дата звернення: 17.02.2021). 12. Про Фонд гарантування вкладів фізичних осіб : Закон України від 20.09.2001 р. N 2740-III. Втрата чинності 21.09.2012 p. URL: https://zakon.rada.gov.ua/laws/show/2740-14\#Text (дата звернення: 17.02.2021). 13. Про систему гарантування вкладів фізичних осіб : Закон України від 23.02.2012 p. № 4452-VI. Оновлено 16.08.2020 p. URL: https://zakon.rada.gov.ua/laws/show/4452-17\#Text (дата звернення: 17.02.2021). 14. Про затвердження Положення про Міністерство фінансів України: Постанова 
Кабінету міністрів України від 20 серпня 2014 р. № 375 . URL: https://zakon.rada.gov.ua/laws/show/375-2014-\%D0\%BF\#Text (дата звернення: 17.02.2021). 15. Про взаєморозуміння та співробітництво між Національним банком України, Національною комісією 3 цінних паперів та фондового ринку, Національною комісією, що здійснює державне регулювання у сфері ринків фінансових послуг, Фондом гарантування вкладів фізичних осіб та Міністерством фінансів України з питань підготовки та впровадження стратегії розвитку фінансового сектору України до 2025 року: Меморандум від 28.05.2019 р. №101215. URL: https://zakon.rada.gov.ua/laws/show/n0397500-19\#Text (дата звернення: 18.02.2021).

\section{REFERENCES:}

1. Kateryna Rozhkova. Yak bankivskyi sektor perezhyv koronakryzu? Tsentr ekonomichnoi stratehii. URL: https://ces.org.ua/yak-bankivskyy-sektor-koronakryzu/ (data zvernennia: 02.03.2021). 2. Pro Natsionalnyi bank Ukrainy : Zakon Ukrainy. Vidomosti Verkhovnoi Rady Ukrainy. № 679-XIV vid 20 travnia 1999 roku. [Chynnyi vid 2021-01-01]. URL: https://zakon.rada.gov.ua/laws/show/679-14/page\#Text (data zvernennia: 17.02.2021). 3. Zvit pro finansovu stabilnist. NBU, hruden 2020. URL: https://bank.gov.ua/admin_uploads/article/FSR_2020-H2.pdf?v=4 (data zvernennia: 09.02.2021). 4. The $\$ 10$ trillion rescue: How governments can deliver impact. URL: https://www.mckinsey.com/ /media/McKinsey/Industries/Public\%20Sector/Our\%201 nsights/The $\% 2010 \% 20$ trillion\%20dollar\%20rescue\%20How\%20governments $\% 20$ can \%20deliver\%20impact/The-10-trillion-dollar-rescue-How-governments-can-deliverimpact-vF.pdf (data zvernennia: 09.02.2021). 5. Stratehiia makroprudentsiinoi polityky. NBU. URL: https://old.bank.gov.ua/doccatalog/document?id=83019081 (data zvernennia: 09.02.2021). 6. NBU : ofitsiinyi sait. https://bank.gov.ua/admin_uploads/article/Strategy_FS_2025.pdf?v=4 (data zvernennia: 09.02.2021). 7. Stratehiia makroprudentsiinoi polityky: NBU. URL: URL: file:///C:/Users/User/Downloads/Strategy_MaP.pdf (data zvernennia: 09.03.2021). 8. Pro Natsionalnyi bank Ukrainy : Zakon Ukrainy vid 20.05.1999 № 679-XIV. Vidomosti Verkhovnoi Rady Ukrainy. 1999. № 29. St. 238. Onovleno 01.01.2021 r. URL: https://zakon.rada.gov.ua/laws/show/679-14/page\#Text (data zvernennia: 17.02.2021). 9. Pro Natsionalnu komisiiu, shcho zdiisniuie derzhavne rehuliuvannia sferi rynkiv finansovykh posluh : Ukaz Prezydenta Ukrainy vid 23.11.2011 № 1070. $\begin{array}{llll}\text { Vtrata chynnosti } & 07.07 .2020 & \text { U. }\end{array}$ https://zakon.rada.gov.ua/laws/show/1070/2011\#Text (data zvernennia: 17.02.2021). 10. Pro prypynennia Natsionalnoi komisii, shcho zdiisniuie derzhavne rehuliuvannia u sferi rynkiv finansovykh posluh : Ukaz Prezydenta Ukrainy vid 30.06.2020 r. № 259/2020. URL: https://zakon.rada.gov.ua/laws/show/259/2020\#Text (data zvernennia: 17.02.2021). 11. Pro Natsionalnu komisiiu z tsinnykh paperiv ta fondovoho rynku : Ukaz Prezydenta Ukrainy vid 23.11.2011 r. № 1063/2011. Onovleno 07.07.2020 r. URL: https://zakon.rada.gov.ua/laws/show/1063/2011\#Text (data zvernennia: 17.02.2021). 12. Pro Fond harantuvannia vkladiv fizychnykh osib : Zakon Ukrainy vid 20.09.2001 r. N 2740-III. Vtrata chynnosti 21.09.2012 r. URL: https://zakon.rada.gov.ua/laws/show/2740-14\#Text (data zvernennia: 17.02.2021). 13. Pro systemu harantuvannia vkladiv fizychnykh osib : Zakon Ukrainy vid 23.02.2012 r. № 4452-VI. Onovleno 16.08 .2020 r. URL: https://zakon.rada.gov.ua/laws/show/4452-17\#Text (data zvernennia: 17.02.2021). 
14. Pro zatverdzhennia Polozhennia pro Ministerstvo finansiv Ukrainy : Postanova Kabinetu ministriv Ukrainy vid 20 serpnia 2014 r. № 375 . URL: https://zakon.rada.gov.ua/laws/show/375-2014-\%D0\%BF\#Text (data zvernennia: 17.02.2021). 15. Pro vzaiemorozuminnia ta spivrobitnytstvo mizh Natsionalnym bankom Ukrainy, Natsionalnoiu komisiieiu z tsinnykh paperiv ta fondovoho rynku, Natsionalnoiu komisiieiu, shcho zdiisniuie derzhavne rehuliuvannia u sferi rynkiv finansovykh posluh, Fondom harantuvannia vkladiv fizychnykh osib ta Ministerstvom finansiv Ukrainy z pytan pidhotovky ta vprovadzhennia stratehii rozvytku finansovoho sektoru Ukrainy do 2025 roku : Memorandum vid 28.05.2019 r. № 101215. URL: https://zakon.rada.gov.ua/laws/show/n0397500-19\#Text (data zvernennia: 18.02.2021).

Небава M. I. [1; ORCID ID: 0000-0001-6933-8702], к.е.н., професор, Li Yanan [1; ORCID ID: 0000-0002-6652-4953], здобувач вищої освіти третього (освітньо-наукового) рівня

${ }^{1}$ Вінницький національний технічний університет, м. Вінниця

\section{НАПРЯМКИ ТА СТРАТЕГІЧНІ ЦІЛІ РОЗВИТКУ БАНКІВСЬКОГО СЕКТОРУ УКРАЇНИ В ПЕРІОД ЕКОНОМІЧНОЇ НЕСТАБІЛЬНОСТІ}

У статті на основі офіційних даних НБУ та висновків експертів банківського ринку досліджено напрямки та стратегічні цілі розвитку банківського сектору країни у період економічної нестабільності. 3'ясовано, що поширення епідемії COVID-19 спричинило економічну нестабільність. На основі закордонного досвіду діяльності центробанків в умовах кризи виокремлено три напрямки антикризових заходів: монетарна політика; інструменти підтримки ліквідності; пруденційний нагляд. Здійснено характеристику умов та ризиків банківського сектору України в умовах кризи. Визначено стратегічні напрямки розвитку банківського сектору, зокрема: фінансова стабільність, макроекономічний розвиток, фінансова інклюзія, розвиток фінансових ринків, інноваційний розвиток. Встановлено, що кожен стратегічний напрям має свої стратегічні цілі. Визначено, що головним завданням Національного банку під час кризи є розробка рекомендацій та оприлюднення планів і намірів для учасників банківської системи на найближчий час. На основі проведених досліджень доведено, що на стабільність і розвиток банківського сектору України має вплив не тільки НБУ, а й інші учасники: Міністерство фінансів України; Національна комісія 3 цінних паперів та фондового ринку; Національна комісія, що здійснює державне регулювання у сфері ринків фінансових послуг; Фонд гарантування вкладів фізичних осіб. Ці учасники забезпечують головну місію - сприяють підвищенню добробуту громадян через забезпечення 
ефективного акумулювання, розподілу та обігу фінансових ресурсів в національній економіці.

Приведено перелік міжнародних організацій, які надають інформаційну підтримку щодо сприяння фінансової стабільності НБУ: BCBS - Базельський Комітет з питань банківського нагляду при Банку міжнародних розрахунків, ESRB - недержавна саморегульована організація, яка займається оцінкою і наступним присвоєнням рейтингу програмному забезпеченню (Entertainment Software Rating Board), норми CRR/CRD IV - закон EC, який регламентує зменшення ймовірності банкрутства банків.

Виокремлено макроекономічні фактори, що в майбутньому визначатимуть розвиток банківського сектору: клієнтоорієнтованість, перегляд нормативної бази, управління технологіями, зниження рівня кіберризиків, фінтех-проєкти та великі IT-компанії, переосмислення трудових ресурсів.

Ключові слова: національна економіка; банківська система; макропруденційне регулювання; макроекономічні фактори; механізм розвитку; учасники банківського сектору; ризики; криза.

Небава Н. И. [1; ORCID ID: 0000-0001-6933-8702], К.э.н., профессор, Li Yanan [1; ORCID ID: 0000-0002-6652-4953], соискатель высшего образования третьего (научнообразовательного) уровня

${ }^{1}$ Винницкий национальный технический университет, г. Винница

\section{НАПРАВЛЕНИЯ И СТРАТЕГИЧЕСКИЕ ЦЕЛИ РАЗВИТИЯ БАНКОВСКОГО СЕКТОРА УКРАИНЫ В ПЕРИОД ЭКОНОМИЧЕСКОЙ НЕСТАБИЛЬНОСТИ}

В статье на основе официальных данных НБУ и выводов экспертов банковского рынка исследованы направления и стратегические цели развития банковского сектора Украины в период экономической нестабильности. Выяснено, что распространение эпидемии COVID-19 привело к экономической нестабильности в стране.

На основе зарубежного опыта деятельности Центробанков в условиях кризиса выделены три направления антикризисных мер: монетарная политика; инструменты поддержки ликвидности; пруденциальный надзор. Осуществлено характеристику условий и рисков банковского сектора Украины в условиях кризиса. Определены стратегические направления развития банковского сектора, в частности: 
финансовая стабильность, макроэкономическое развитие, финансовая инклюзия, развитие финансовых рынков, инновационное развитие.

Установлено, что каждое направление имеет свои стратегические цели. Определено, что главной задачей Национального банка во время кризиса является разработка рекомендаций и обнародования планов и намерений для участников банковской системы на ближайшее время. На основе проведенных исследований доказано, что на стабильность и развитие банковского сектора Украины имеет влияние не только НБУ, но и другие участники: Министерство финансов Украины; Национальная комиссия по ценным бумагам и фондовому рынку; Национальная комиссия, осуществляющая государственное регулирование в сфере рынков финансовых услуг; Фонд гарантирования вкладов физических лиц. Эти участники обеспечивают главную миссию - способствуют повышению благосостояния граждан путем обеспечения эффективного аккумулирования, распределения и обращения финансовых ресурсов в национальной экономике.

Приведен перечень международных организаций, которые предоставляют информационную поддержку по содействию финансовой стабильности НБУ: ВСВS - Базельский комитет по банковскому надзору при Банке международных расчетов, ESRB - негосударственная саморегулируемая организация, которая занимается оценкой и последующим присвоением рейтинга программному обеспечению, нормы CRR / CRD IV - закон EC, регламентирующий уменьшения вероятности банкротства банков.

Выделены макроэкономические факторы, В будущем будут определять развитие банковского сектора: клиентоориентированность, пересмотр нормативной базы, управление технологиями, снижение уровня киберрисков, финтех-проекты и большие ИТ-компании, переосмысление трудовых ресурсов.

Ключевые слова: национальная экономика; банковская система; макропруденциальное регулирование; макроэкономические факторы; механизм развития; участники банковского сектора; риски; кризис. 